PENENTUAN NASABAH PENERIMA REWARD PRODUK GOLD DENGAN METODE SIMPLE ADDITIVE WEIGHTING (SAW) STUDI KASUS : PT. PINJAM INDONESIA

Riki Ruli A. Siregar; Faizal Fachrurrozi

IMPLEMENTASI METODE BACKWARD CHAINING PADA DATA WAREHOUSE DAOP 1 JAKARTA PT. KAI (PERSERO) Rakhmat Arianto; Chandra Bagus Sugiarto

IMPLEMENTASI METODE DETEKSI TEPI CANNY PADA OBJEK SEBAGAI MODEL KEAMANAN APLIKASI PADA SMARTPHONE ANDROID

Abdul Haris; Andi Prasetyo

ANALISA DATA DAN PERANCANGAN APLIKASI SERVICE PELANGGAN PT. JNE UNTUK PENINGKATAN KUALITAS LAYANAN

Dewi Arianti Wulandari; Sonny Syahrindra Putra

JARINGAN AD-HOC VEHICULAR (VANET) : TINJAUAN TENTANG ARSITEKTUR, KARAKTERISTIK, APLIKASI, DAN PROTOKOL MEDIUMACCESS CONTROL (MAC)

Rosida Nur Aziza

PERANCANGAN APLIKASI PENJADWALAN MATA KULIAH MENGGUNAKAN METODE CONSTRAINT PROGRAMMING Syam Gunawan

RANCANGAN TATA KELOLA PEREMAJAAN RUANG KELAS DIREKTORAT PEMBINAAN SEKOLAH DASAR

Ratna Mutu Manikam; Purwanto

PENGEMBANGAN AMORIK MENGGUNAKAN METODE GARIS SINGGUNG TERHADAP DUA LINGKARAN DAN PERSAMAAN KURVA BEZIER ORDE DUA.

Darma Rusjidi

OPTIMALISASI PENGAMBILAN KEPUTUSAN PENILAIAN KINERJA DOSEN PADA PERGURUAN TINGGI ISLAM XYZ MENGGUNAKAN AHP (ANALYTICAL HIERARCHY PROCESS)

Rahma Farah Ningrum

PENGAMANAN SMS PADA TELEPON SELULER BERBASIS ANDROID MENGGUNAKAN ALGORITMA TRIPLE DES Raka Yusuf; $M$. Rival Suheri

APLIKASI LATIHAN SOAL UJIAN TEORI SURAT IZIN MENGEMUDI BERBASIS WEB Harni Kusniyati; Raka Yusuf; Andri Setiawan

RANCANG BANGUN SIMULASI TERJADINYA LISTRIK DENGAN SUMBER DAYA SAMPAH BERBASIS MULTIMEDIA (STUDI KASUS : TPST BANTAR GEBANG)

Yasni Djamain; Ika Fitriyani Putri

\begin{tabular}{|c|c|c|c|c|c|c|}
\hline \multirow{2}{*}{ 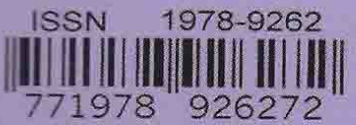 } & \multicolumn{6}{|c|}{ SEKOLAH TINGGI TEKNIK - PLN (STT-PLN) } \\
\hline & PETIR & VOL. 9 & No. 1 & HAL. 1 - 87 & JAKARTA, MARET 2016 & ISSN $1978-9262$ \\
\hline
\end{tabular}




\title{
PENENTUAN NASABAH PENERIMA REWARD PRODUK GOLD DENGAN METODE SIMPLE ADDITIVE WEIGHTING (SAW) STUDI KASUS : PT. PINJAM INDONESIA
}

\author{
Riki Ruli A. Siregar; Faizal Fachrurrozi \\ Program Studi Teknik Informatika Sekolah Tinggi Teknik PLN Jakarta \\ ruliriki@gmail.com ichal.coffee@gmail.com
}

\begin{abstract}
ABSTRAK
Sebagai apresiasi kepada nasabah, PT Pinjam Indonesia memiliki produk Gold berupa potongan sebesar 10\% total tagihan yang diberikan kepada dua orang nasabah tiap 6 bulan. Saat ini PT Pinjam Indonesia dalam menentukan nasabah penerima produk gold pada Sistem Pegadaian Online mengalami kesulitan karena banyaknya nasabah.

Oleh karena itu diperlukan suatu Sistem Pendukung Keputusan yang dapat membantu mempercepat dan mempermudah proses pengambilan keputusan. Sistem pendukung keputusan menentukan alternatif nilai terbaik yang layak menerima produk Gold menggunakan Simple Additive Weighting (SAW) dengan kriteria yang telah ditentukan. Konsep dasar Metode Simple Additive Weighting (SAW) adalah mencari penjumlahan terbobot dari rating kinerja pada setiap alternatif pada semua atribut.

Metode SAW membutuhkan proses normalisasi matriks keputusan ke suatu skala yang dapat di perbandingkan dengan semua rating alternatif yang ada. Dari kriteria yang ada dilakukan proses perhitungan untuk mendapatkan hasil alternatif terbaik penerima produk Gold sehingga dapat memberikan rekomendasi nasabah penerima produk Gold yang lebih objektif
\end{abstract}

Kata kunci: Sistem Pegadaian Online, produk Gold, nasabah, Simple Additive Weighting (SAW).

\section{ABSTRACT}

As an appreciation to their customer, PT Pinjam Indonesia has a Gold product. Gold is a product that allows customer to get 10\% discount of total bill every 6 months, and is given to two customers. Until now, PT Pinjam Indonesia has difficulties in deciding which customer from Online mortgage system deserves to be rewarded with the Gold product, this problem occurs because of the many numbers of customer in the system.

Therefore, Decision Support System is needed to help speed up and make the deciding process easier. Decision Support System decide the highest alternative value that deserves to receive the Gold product using the Simple Additive Weighting (SAW) method wtih prescribedcriterias. The basic concept of Simple Additive Weighting (SAW) method is to find the weighted additive from performance rating of every alternative's attributes.

SAW method needs a normalization process of the decision matrix to a scale that can be compared with every rated alternatives. A calculation process is applied to all the criterias to get the result of which alternative is best to receive the Gold product. This method could help the decision making process to be more objective.

Keyword: Online mortgage system, Gold product, customer, Simple Additive Weighting (SAW).

\section{PENDAHULUAN}

\subsection{Latar Belakang}

PT. Pinjam Indonesia merupakan salah satu lembaga keuangan non-bank yang bergerak di bidang pinjaman kredit. Sebagai apresiasi kepada nasabah, PT Pinjam Indonesia memiliki produk Gold berupa potongan sebesar $10 \%$ total tagihan yang diberikan kepada dua orang nasabah setiap 6 bulan. Saat ini PT Pinjam Indonesia dalam menentukan nasabah penerima produk Gold mengalami kesulitan karena banyaknya nasabah dan adanya beberapa kriteria yang digunakan. Oleh karena itu diperlukan suatu Sistem Pendukung Keputusan yang dapat membantu mempercepat dan mempermudah proses pengambilan keputusan. Sistem Pendukung
Keputusan ini akan diintegrasikan ke dalam Sistem Pegadaian Online.

Metode yang digunakan adalah Simple Additive Weighting (SAW). Metode tersebut dipilih karena dalam penentuan produk Gold terdapat kriteria-kriteria yang telah ditentukan dengan nasabah sebagai alternatifnya dan prioritas dari kriteria itu sebagai nilai bobot. SAW sering juga dikenal istilah metode penjumlahan terbobot. Konsep dasar metode SAW adalah mencari penjumlahan terbobot dari rating kinerja pada setiap alternatif pada semua atribut (Fishburn, 1967) (MacCrimmon, 1968). Dengan metode ini penentuan nasabah penerima produk Gold akan lebih tepat karena didasarkan pada nilai kriteria dan bobot yang sudah ditentukan. 


\subsection{Rumusan Masalah}

Berdasarkan latar belakang pemilihan judul di atas, dapat dirumuskan permasalahan sebagai berikut :

1. Bagaimana menerapkan metode Simple Additive Weighting ke Sistem Pegadaian Online untuk menentukan nasabah penerima produk Gold menggunakan data bulan Maret - Agustus tahun 2015 ?

\subsection{Tujuan}

Tujuan penelitian ini adalah menerapkan metode Simple Additive Weighting (SAW) sehingga dapat membantu mempercepat pengambilan keputusan dalam menentukan nasabah penerima produk Gold pada PT Pinjam Indonesia.

\section{LANDASAN TEORI}

\subsection{Produk Gold}

Produk Gold adalah suatu penawaran yang diberikan untuk mengapresiasi nasabah dari PT. Pinjam Indonesia. Produk ini diberikan berdasarkan catatan/track record dari suatu anggota selama enam bulan. Dalam enam bulan tersebut hanya dua orang yang berhak mendapatkan produk Gold yaitu potongan 10\% dari total tagihan.

\subsection{Simple Additive Weighting (SAW)}

Metode Simple Additive Weighting (SAW) sering juga dikenal istilah metode penjumlahan terbobot. Konsep dasar metode SAW adalah mencari penjumlahan terbobot dari rating kinerja pada setiap alternatif pada semua atribut (Fishburn, 1967) (MacCrimmon, 1968). Metode SAW membutuhkan proses normalisasi matriks keputusan (X) ke suatu skala yang dapat diperbandingkan dengan semua rating alternatif yang ada.

$r_{i j}= \begin{cases}\frac{x_{i j}}{\operatorname{Max}_{i j}\left(x_{i j}\right)} \text { Jika jadalah kriteria keuntungan (benefit) } \\ \frac{\operatorname{Min}_{i j}\left(x_{i j}\right)}{x_{i j}} \quad \text { Jika j adalah kriteria biaya (cost) }\end{cases}$

Keterangan :

1. Dikatakan kriteria keuntungan apabila nilai

$x_{i j}$ memberikan keuntungan bagi pengambil keputusan, sebaliknya kriteria biaya apabila

$x_{i j}$ menimbulkan biaya bagi pengambil keputusan

2. Apabila berupa kriteria keuntungan maka nilai $x_{i j}$ dibagi dengan nilai $\operatorname{Hax}_{t}\left(x_{t j}\right)$ dari setiap kolom, sedangkan untuk kriteria biaya, nilai $\mathrm{HL}_{t}\left(x_{t j}\right)$ dari setiap kolom dibagi dengan nilai $x_{i j}$

Nilai Preferensi untuk setiap alternative (Vi) diberikan sebagai :
$V i=\sum_{j=1}^{n} w_{j} r_{i j}$

Keterangan :

$\mathrm{Vi}=$ ranking untuk setiap alternative

$\mathrm{w}_{\mathrm{j}}=$ nilai bobot dari setiap kriteria

$r_{i j}=$ nilai rating kinerja ternormalisasi

Nilai Vi yang lebih besar mengindikasikan bahwa alternative $A$, merupakan alternatif terbaik.

Langkah Perhitungan Metode SAW

1. Menentukan alternatif, yaitu $A_{i}$.

2. Menentukan kriteria yang akan dijadikan acuan dalam pengambilan keputusan yaitu $C_{j}$.

3. Menentukan bobot preferensi atau tingkat kepentingan $(w)$ setiap kriteria.

$w=\left[\begin{array}{lllll}w_{1} & w_{2} & w_{3} & \ldots . & w_{j}\end{array}\right]$

4. Membuat tabel rating kecocokan setiap alternatif pada setiap kriteria.

5. Membuat matrik keputusan $X$ yang dibentuk dari tabel rating kecocokan dari setiap alternatif pada setiap kriteria. Nilai $\{x\}$ setiap alternatif $(\mathrm{Ai})$ pada setiap kriteria $(\mathrm{Cj})$ yang sudah ditentukan dimana, $\mathrm{I}=1,2, \ldots, \mathrm{m}$ dan $\mathrm{j}=$ $1,2, \ldots, n$.

6. Melakukan normalisasi matrik keputusan $X$ dengan cara menghitung nilai rating kinerja ternormalisasi $\left(r_{i j}\right)$ dari alternative $\left(A_{i}\right)$ pada kriteria $\left(C_{j}\right)$.

7. Hasil dari nilai rating kinerja ternormalisasi $\left(r_{i j}\right)$ membentuk matrik ternormalisasi (R).

$$
R=\left[\begin{array}{cccc}
r_{11} & r_{12} & \ldots & r_{1 j} \\
\vdots & & & \vdots \\
r_{i 1} & r_{i 2} & \ldots & r_{i j}
\end{array}\right]
$$

8. Hasil akhir nilai preferensi $\left(\mathrm{V}_{\mathrm{i}}\right)$ diperoleh dari penjumlahan dari perkalian elemen baris matrik ternormalisasi ( $r$ ) dengan bobot preferensi (W) yang bersesuaian elemen kolom matrik $(w)$.

\section{METODOLOGI PENELITIAN}

\subsection{Kerangka Pemikiran}

Dibawah ini merupakan kerangka pemikiran yang lakukan. Kerangka pemikiran tersebut merupakan tahap proses dari awal pembuatan hingga akhir penyusunan. 


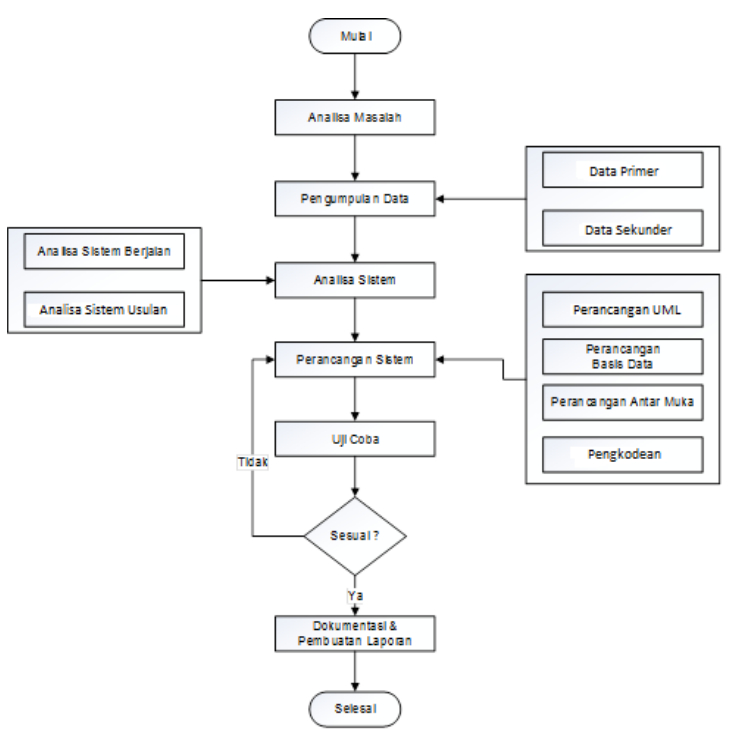

Gambar 1. Kerangka Pemikiran

\subsection{Kerangka Pemikiran}

Keseluruhan tahapan penelitian diatas akan dijelaskan tahap demi tahap sebagai berikut :

\subsubsection{Analisa Masalah}

Identifikasi masalah dilakukan dengan cara mempelajari masalah-masalah yang timbul dalam sistem pegadaian online antara lain banyaknya nasabah dan data masih bersifat fisik. Penentuan penerima produk Gold berdasarkan Jumlah Kontrak, Total Pinjaman, Rata-rata Durasi dan Bobot Status. Namun sistem pegadaian online ini memiliki kendala yang dapat menghambat pengambilan keputusan terhadap produk Gold tersebut, diantaranya sebagai berikut :

a. Sulit menentukan nasabah yang berhak menerima produk Gold.

b. Penerima produk Gold subyektif.

\subsubsection{Pengumpulan Data}

Pengumpulan data adalah mengumpulkan bahan-bahan yang diperlukan dalam penelitian ini, dengan menggunakan metode data primer dan data sekunder.

\section{A. Data Primer}

Merupakan mempelajari data yang didapatkan langsung dari PT Pinjam Indonesia. Data yang didapatkan dari PT Pinjam Indonesia berupa laporan transaksi nasabah periode bulan Maret sampai dengan Agustus tahun 2015.

\section{B. Data Sekunder}

Metode studi pustaka dilakukan dengan mengumpulkan data dan informasi yang dijadikan sebagai acuan dalam mengembangkan sistem pegadaian online. Selain itu, pendekatan tentang pemrograman PHP dan metode Simple Additive Weighting (SAW). Referensi-referensi tersebut berasal dari buku-buku pegangan maupun publikasi hasil penelitian, artikel, situs internet serta sumber informasi lain yang berkaitan dengan penelitian ini.

\subsubsection{Analisa Sistem}

Proses melakukan identifikasi proses sistem berjalan dan sistem kebutuhan, dimana hasil dari analisa digunakan untu membuat skema alur proses sistem pegadaian online. Dengan juga melakukan identifikasi informasi yang dibutuhkan untuk membangun sistem yang diusulkan. Informasi yang didapat akan digunakan untuk membangun sistem yang akan diusulkan dengan mengikuti skema alur proses sistem yang telah dianalisa.

\section{A. Analisa Sistem Berjalan}

Pada saat ini sistem yang sedang berjalan di PT Pinjam Indonesia yaitu admin harus melakukan rekap laporan pinjaman tiap enam bulan sekali. Selanjutnya admin melakukan pengelompokan berdasarkan anggota. Kemudian admin dapat menentukan nasabah yang berhak mendapatkan produk Gold.

Penentuan produk Gold yang diberikan kepada nasabah belum memiliki nilai baku sehingga admin mengambil keputusan berdasarkan diri admin sendiri (subyektif).

Berikut ini gambaran sistem yang berjalan:

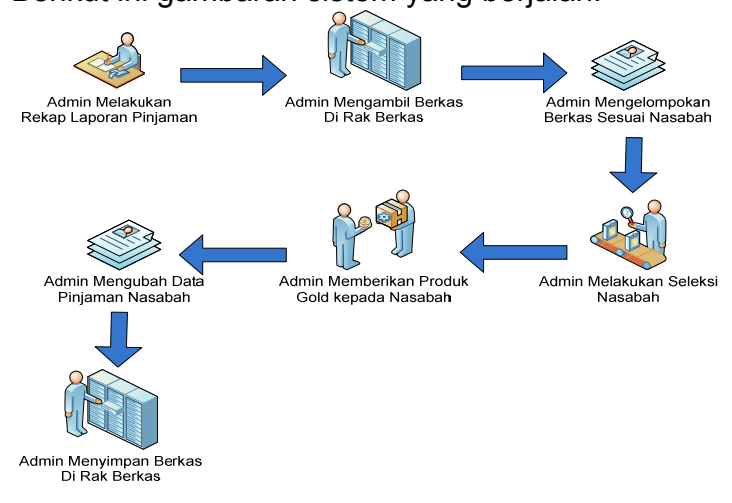

Gambar 2 Sistem Berjalan

Pada sistem yang berjalan saat ini terdapat kendala yaitu pengumpulan berkas secara manual, admin harus menentukan nasabah penerima produk Gold secara manual kemudian membuat data pinjaman baru untuk melakukan update potongan total tagihan nasabah yang mendapat produk Gold.

\section{B. Analisa Sistem Usulan}

Analisa sistem usulan dilakukan dengan tujuan untuk menggambarkan secara garis besar sistem yang diusulkan. Dalam kasus untuk mengusulkan dengan menerapkan metode Simple Additive Weighting dalam Sistem Pegadaian Online. Berikut ini adalah rancangan sistem usulan: 


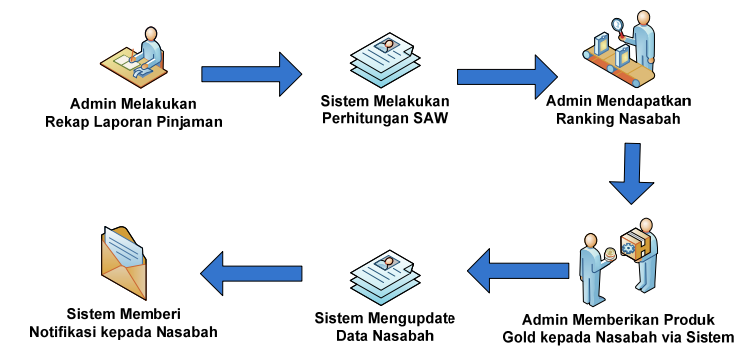

Gambar 3. Sistem Usulan

Pada gambar diatas admin harus login terlebih dahulu ke Administrasi Sistem Pegadaian Online, kemudian masuk ke menu promosi. Kemudian admin memilih periode dan tahun yang ingin diterapkan. Sistem akan melakukan proses perhitungan menggunakan metode Simple Additive Weighting (SAW). Admin akan mendapatkan hasil ranking dari nasabah yang melakukan transaksi selama 6 bulan tersebut. Admin akan menetapkan 2 nasabah yang berhak mendapatkan produk Gold berdasarkan rekomendasi sistem. Sistem secara otomatis akan memotong $10 \%$ total tagihan dari anggota yang mendapatkan produk Gold.

\subsubsection{Perancangan Sistem}

A. Perancangan Sistem (UML)

Merepresentasikan gambaran dari sistem yang dibuat dengan menggunakan notasi UML.

B. Perancangan Basis Data

Proses perancangan basis data ini adalah merancang kebutuhan tabel yang akan digunakan untuk penyimpanan data.

C. Perancangan Antar Muka

Merancang antar muka yang merupakan antar muka interaktif antara user dengan sistem.

D. Pengkodean

Perancangan akan diimplementasikan dengan menggunakan bahasa pemrograman PHP dibantu framework Code Igniter dan basis data diimplementasikan dengan MySQL.

\subsection{Usecase Diagram}

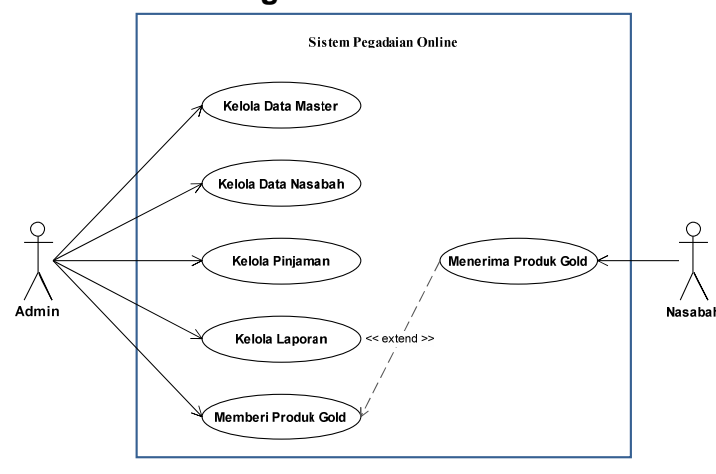

Gambar 4. Use Diagram

Usecase diagram digunakan untuk menspesifikasikan apa yang dapat dilakukan oleh sistem atau untuk menspesifikasikan kebutuhan fungsional utama dari sistem. Pada diagram usecase di atas terdapat dua aktor yaitu admin dan nasabah. Setiap aktor memiliki kewenangan masing-masing.

\section{Penentuan Kriteria dan Sub Kriteria}

Dalam penelitian ini menggunakan metode Simple Additive Weighting. Adapun langkahlangkahnya adalah :

1. Menentukan kriteria-kriteria yang akan dijadikan acuan dalam pengambilan keputusan.

2. Menentukan rating kecocokan setiap alternatif pada setiap kriteria.

3. Membuat matriks keputusan berdasarkan Sub kriteria (Ci), kemudian melakukan normalisasi matriks berdasarkan persamaan yang disesuaikan dengan jenis atribut (atribut keuntungan ataupun atribut biaya) sehingga di peroleh matriks ternormalisasi $R$.

4. Hasil akhir diperoleh dari proses perangkingan yaitu penjumlahan dari perkalian matriks ternormalisasi $\mathrm{R}$ dengan vektor bobot sehingga diperoleh nilai terbesar yang dipilih sebagai alternatif terbaik ( $\mathrm{Ai})$ sebagai solusi.

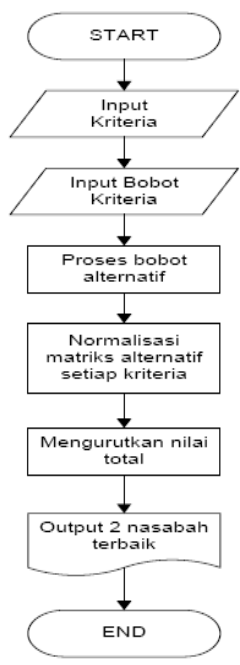

Gambar. 5 Diagram Alir Model SAW

Dalam seleksi penerima produk gold pada PT Pinjam Indonesia menggunakan Simple Additive Weighting (SAW) diperlukan kriteria dan bobot untuk melakukan perhitungannya sehingga akan didapat alternatif terbaik. Bobot ditentukan sesuai dengan prioritas yang ditetapkan PT Pinjam Indonesia. Adapun kriteria adalah sebagai berikut :

Tabel 1. Penentuan Kriteria

\begin{tabular}{|c|c|c|}
\hline Alternatif & Kriteria & Keterangan \\
\hline \multirow{4}{*}{$\mathrm{Ai}$} & $\mathrm{C} 1$ & Jumlah Kontrak \\
\cline { 2 - 3 } & $\mathrm{C} 2$ & Total Pinjaman \\
\cline { 2 - 3 } & $\mathrm{C} 3$ & Rata-rata Durasi \\
\cline { 2 - 3 } & $\mathrm{C} 4$ & Status \\
\hline
\end{tabular}


Kriteria tersebut ditentukan oleh PT Pinjam Indonesia. Berikut penjelasan dari setiap kriteria :

1. Jumlah Kontrak adalah jumlah kontrak yang dibuat nasabah selama periode 6 bulan.

2. Total Pinjaman adalah akumulasi pinjaman yang dilakukan oleh nasabah dalam periode 6 bulan.

3. Rata-rata durasi yang diambil dalam periode 6 bulan.

4. Status dari setiap pinjaman yang dilakukan nasabah selama 6 bulan.

Dari masing-masing kriteria tersebut diberikan nilai yaitu :

1. Jumlah Kontrak

Tabel 2. Jumlah Kontrak dan Nilai

\begin{tabular}{|l|l|c|}
\hline Jumlah Kontrak & Nilai & Keterangan \\
\hline 1 & 1 & Rendah \\
\hline 2 & 3 & Sedang \\
\hline$>2$ & 5 & Tinggi \\
\hline
\end{tabular}

Tabel 3. Jumlah Pinjaman

\begin{tabular}{|r|c|}
\hline Total Pinjaman & Keterangan \\
\hline$<1.000 .000$ & Rendah \\
\hline $\begin{array}{c}1.000 .000- \\
6.000 .000\end{array}$ & Sedang \\
\hline$>6.000 .000$ & Tinggi \\
\hline
\end{tabular}

Tabel 4. Durasi Peminjaman

\begin{tabular}{|l|l|c|}
\hline Durasi & Nlai & Keterangan \\
\hline 1 - 4 Minggu & 1 & Rendah \\
\hline 5 - 8 Minggu & 3 & Sedang \\
\hline $9-12$ Minggu & 5 & Tinggi \\
\hline
\end{tabular}

Tabel 5. Status

\begin{tabular}{|l|c|c|}
\hline Status & Nlai & Keterangan \\
\hline EXTENDED, LATE & 1 & Rendah \\
\hline ONGOING & 3 & Sedang \\
\hline CLOSED & 5 & Tinggi \\
\hline
\end{tabular}

3.3 Analisis Penentuan Penerima Produk Gold Dengan SAW

Dalam penentuan penerima produk Gold dilakukan penyeleksian setiap nasabah dengan dibantu dengan kriteria yang telah ditentukan sebelumnya. Tahap pengolahan data dengan Metode Simple Additive Weighting sebagai berikut:

1. Melakukan identifikasi kriteria produk Gold

$\begin{array}{ll}\text { Kriteria } & \text { Keterangan } \\ \text { C1 } & \text { Jumlah Kontrak } \\ \text { C2 } & \text { Total Pinjaman } \\ \text { C3 } & \text { Rata-rata Durasi } \\ \text { C4 } & \text { Status }\end{array}$

Tabel 5. Tabel Nasabah Calon Penerima Produk Gold

\begin{tabular}{|l|c|c|c|c|}
\hline \multirow{2}{*}{ Alternatif } & \multicolumn{4}{|c|}{ Kriteria } \\
\cline { 2 - 5 } & $\begin{array}{c}\text { Alternatif } \\
\text { Jumlah } \\
\text { Kontrak }\end{array}$ & $\begin{array}{c}\text { Total } \\
\text { Pinjaman }\end{array}$ & $\begin{array}{c}\text { Rata } \\
\text { Durasi }\end{array}$ & Status \\
\hline ELIYA NUR HAYA & 2 & 6.500 .000 & 8 & 4 \\
\hline FAIZAL FACHRURROZI & 1 & 30.000 .00 & 12 & 5 \\
\hline ELVIN TRIPUTRA & 1 & 1.500 .000 & 8 & 3 \\
\hline ALI FIRDAUS & 1 & 1.500 .000 & 4 & 3 \\
\hline MARLA HAIFA & 1 & 500.000 & 4 & 5 \\
\hline FUAD BALAFIF & 1 & 770.000 & 4 & 3 \\
\hline
\end{tabular}

2. Kemudian data pada tabel 3.6 dicocokan dengan nilai yang sesuai dengan kriteria masing-masing.

Tabel 6. Rating Kecocokan Setiap Kriteria

\begin{tabular}{|l|l|l|l|l|}
\hline \multirow{2}{*}{ Alternatif } & \multicolumn{4}{|c|}{ Kriteria } \\
\cline { 2 - 5 } & $\begin{array}{c}\text { Alternatif } \\
\text { Jumlah } \\
\text { Kontrak }\end{array}$ & $\begin{array}{l}\text { Total } \\
\text { Pinjaman }\end{array}$ & $\begin{array}{l}\text { Rata } \\
\text { Durasi }\end{array}$ & Status \\
\hline ELIYA NUR HAYA & 3 & 5 & 5 & 4 \\
\hline FAIZAL FACHRURROZI & 1 & 5 & 5 & 5 \\
\hline ELVIN TRIPUTRA & 1 & 3 & 5 & 3 \\
\hline ALI FIRDAUS & 1 & 3 & 1 & 3 \\
\hline MARLA HAIFA & 1 & 1 & 1 & 5 \\
\hline FUAD BALAFIF & 1 & 1 & 1 & 3 \\
\hline
\end{tabular}

3. Membuat matrik keputusan yang dibentuk dari tabel rating kecocokan dari setiap alternatif pada setiap kriteria.

$$
X=\left[\begin{array}{llll}
3 & 5 & 5 & 4 \\
1 & 5 & 5 & 5 \\
1 & 3 & 5 & 3 \\
1 & 3 & 1 & 3 \\
1 & 1 & 1 & 5 \\
1 & 1 & 1 & 3
\end{array}\right]
$$

4. Melakukan proses normalisasi matrik keputusan dengan cara menghitung nilai rating kinerja ternomalisasi (rij) berdasarkan persamaan yang disesuaikan dengan jenis kriteria. Untuk kriteria evaluasi administrasi dan evaluasi teknis menggunakan kriteria keuntungan (benefit) sedangkan untuk kriteria harga menggunakan kriteria biaya (cost). 


$$
\begin{gathered}
r_{11}=\frac{3}{\operatorname{Max}(3,1,1,1,1,1)}=\frac{3}{3}=1 \\
r_{21}=\frac{1}{\operatorname{Max}(3,1,1,1,1,1)}=\frac{1}{3}=0.3 \\
r_{51}=\frac{1}{\operatorname{Max}(3,1,1,1,1,1)}=\frac{1}{3}=0.3 \\
r_{61}=\frac{1}{\operatorname{Max}(3,1,1,1,1,1)}=\frac{1}{3}=0.3 \\
r_{12}=\frac{5}{\operatorname{Max}(5,5,3,3,1,1)}=\frac{5}{5}=1 \\
r_{22}=\frac{5}{\operatorname{Max}(5,5,3,3,1,1)}=\frac{5}{5}=1 \\
r_{32}=\frac{3}{\operatorname{Max}(5,5,3,3,1,1)}=\frac{3}{5}=0.6 \\
r_{42}=\frac{3}{\operatorname{Max}(5,5,3,3,1,1)}=\frac{3}{5}=0.6 \\
r_{52}=\frac{1}{\operatorname{Max}(5,5,3,3,1,1)}=\frac{1}{5}=0.2 \\
r_{62}=\frac{1}{\operatorname{Max}(5,5,3,3,1,1,1)}=\frac{1}{5}=0.2 \\
r_{13}=\frac{5}{\operatorname{Max}(5,5,5,1,1,1)}=\frac{5}{5}=1 \\
r_{23}=\frac{5}{\operatorname{Max}(5,5,5,1,1,1)}=\frac{5}{5}=1
\end{gathered}
$$

$$
\begin{gathered}
r_{31}=\frac{1}{\operatorname{Max}(3,1,1,1,1,1)}=\frac{1}{3}=0.3 \\
r_{41}=\frac{1}{\operatorname{Max}(3,1,1,1,1,1)}=\frac{1}{3}=0.3 \\
r_{33}=\frac{5}{\operatorname{Max}(5,5,5,1,1,1)}=\frac{5}{5}=1 \\
r_{43}=\frac{1}{\operatorname{Max}(5,5,5,1,1,1)}=\frac{1}{5}=0.2 \\
r_{53}=\frac{1}{\operatorname{Max}(5,5,5,1,1,1)}=\frac{1}{5}=0.2 \\
r_{63}=\frac{1}{\operatorname{Max}(5,5,5,1,1,1)}=\frac{1}{5}=0.2 \\
r_{14}=\frac{4}{\operatorname{Max}(4,5,3,3,5,3)}=\frac{4}{5}=0.8 \\
r_{24}=\frac{5}{\operatorname{Max}(4,5,3,3,5,5)}=\frac{5}{5}=1 \\
r_{34}=\frac{3}{\operatorname{Max}(4,5,3,3,5,3)}=\frac{3}{5}=0.6 \\
r_{44}=\frac{3}{\operatorname{Max}(4,5,3,3,5,3)}=\frac{3}{5}=0.6 \\
r_{54}=\frac{5}{\operatorname{Max}(4,5,3,3,5,3)}=\frac{5}{5}=1 \\
r_{64}=\frac{3}{\operatorname{Max}(4,5,3,3,5,3)}=\frac{3}{5}=0.6
\end{gathered}
$$

5. Hasil dari rating kinerja kinerja ternormalisasi akan membentuk matrik ternormalisasi

$$
X=\left[\begin{array}{cccc}
1 & 1 & 1 & 0.8 \\
0.3 & 1 & 1 & 1 \\
0.3 & 0.6 & 1 & 0.6 \\
0.3 & 0.6 & 0.2 & 0.6 \\
0.3 & 0.2 & 0.2 & 1 \\
0.3 & 0.2 & 0.2 & 0.6
\end{array}\right]
$$

6. Pemberian nilai bobot (W) pada kriteria

Tabel 7. Tabel Bobot Kriteria

\begin{tabular}{|l|l|c|}
\hline Kriteria & \multicolumn{1}{|c|}{ Keterangan } & Nilai Bobot (W) \\
\hline C1 & Jumlah Kontrak & $35 \%$ \\
\hline C2 & Total Pinjaman & $35 \%$ \\
\hline C3 & Rata Durasi & $20 \%$ \\
\hline C4 & Status & $10 \%$ \\
\hline
\end{tabular}

7. Perhitungan nilai preferensi dari setiap alternative nasabah sebagai berikut:

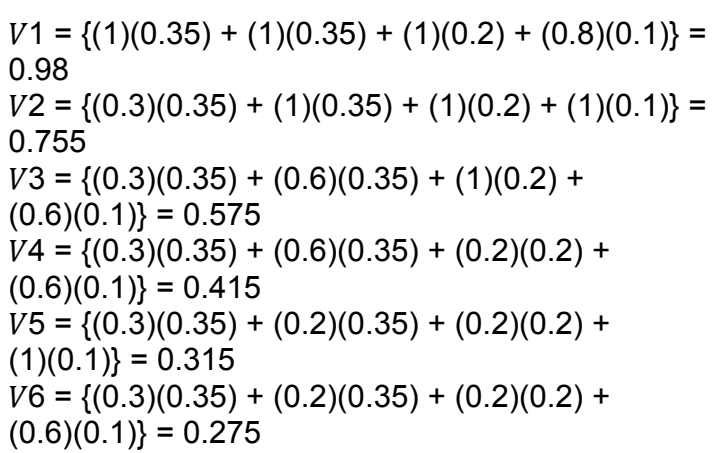

Tabel 8. Proses Perankingan Nasabah

\begin{tabular}{|r|l|c|c|c|c|c|}
\hline \multirow{2}{*}{ No. } & \multirow{2}{*}{ Alternatif } & \multicolumn{4}{|c|}{ Bobot Perankingan } & \multirow{2}{*}{ Hasil } \\
\cline { 3 - 7 } & & $\begin{array}{c}\text { No. } \\
\text { Alternatif } \\
\text { W1 }\end{array}$ & W2 & W3 & W4Hasil & \\
\hline 1 & ELIYA NUR HAYA & 0.35 & 0.35 & 0.2 & 0.08 & 0.98 \\
\hline 2 & FAIZAL FACHRURROZI & 0.105 & 0.35 & 0.2 & 0.1 & 0.755 \\
\hline 3 & ELVIN TRIPUTRA & 0.105 & 0.21 & 0.2 & 0.06 & 0.575 \\
\hline 4 & ALI FIRDAUS & 0.105 & 0.21 & 0.04 & 0.06 & 0.415 \\
\hline 5 & MARLA HAIFA & 0.105 & 0.07 & 0.04 & 0.1 & 0.315 \\
\hline 6 & FUAD BALAFIF & 0.105 & 0.07 & 0.04 & 0.06 & 0.275 \\
\hline
\end{tabular}

8. Untuk nasabah penerima produk Gold diambil dua nilai tertinggi dari Alternatif yaitu :

\section{ELIYA NUR HAYA \\ 0.98 \\ FAIZAL FACHRURROZI \\ 0.755}

\section{HASIL DAN UJI COBA}

Sistem Pegadaian Online yang dibangun merupakan aplikasi berbasis web yang menggunakan framework Code Igniter dan bahasa pemrograman PHP. Secara garis besar Sistem Pegadaian Online ini dirancang untuk membantu mempermudah proses administrasi dan transaksi yang dilakukan pada PT Pinjam Indonesia, diharapkan baik dari pihak perusahaan dan nasabah yang menggunakan akan dimudahkan dengan adanya aplikasi ini.

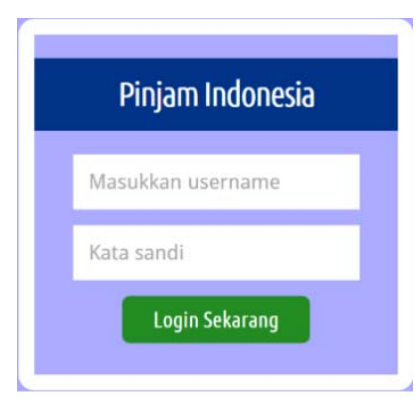

Gambar 6. Halaman Login

Pada menu Login di atas hanya dapat diakses oleh admin dari PT Pinjam Indonesia dikarenakan akan masuk ke dalam Sistem Administrasi dari Pegadaian Online ini.

Setelah berhasil melakukan log in maka akan masuk halaman utama. Tampilan halaman utama adalah sebagai berikut.

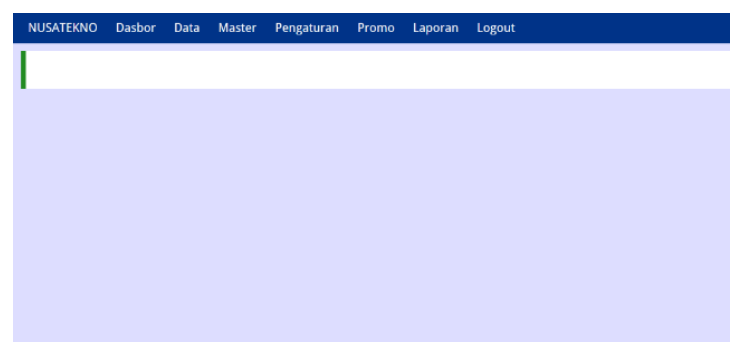

Gambar 7. Halaman Utama 


\subsection{Halaman Master}

Pada halaman Master, pengguna dapat menambahkan, mengedit dan menghapus berbagai item referensi yang sering digunakan pada proses administrasi. Salah satu item tersebut adalah Jenis Barang. Berikut merupakan tampilan menu Master yang tersedia.

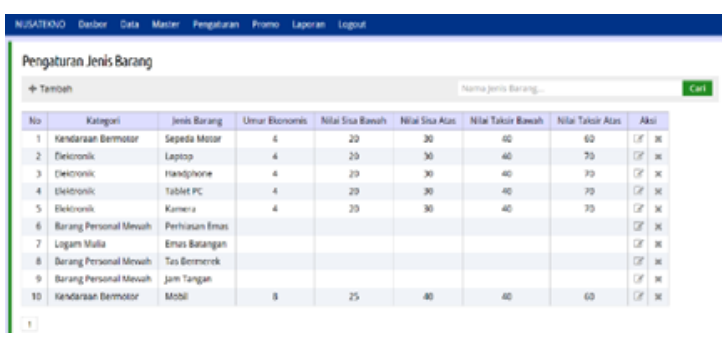

\section{Gambar 8. Halaman Master}

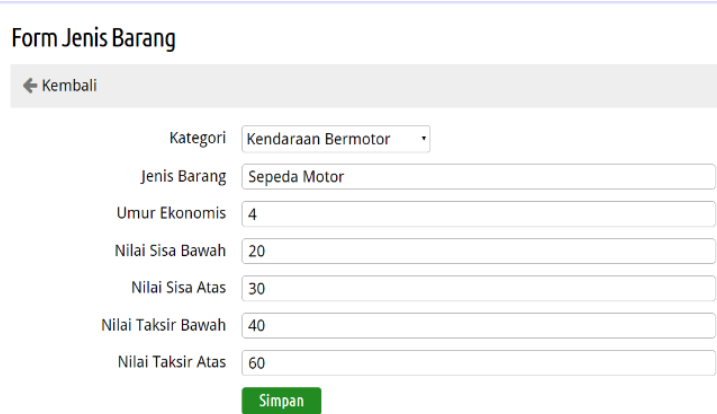

\section{Gambar 9. Form Master}

\subsection{Halaman Nasabah}

Pada Halaman Nasabah admin dapat mengelola data nasabah seperti tambah, update, lihat dan hapus nasabah.

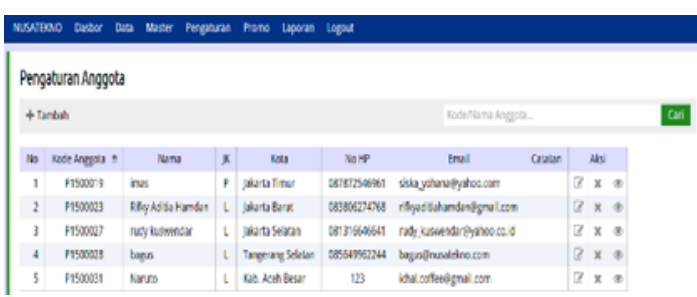

\section{Gambar 10. Halaman Nasabah}

Admin juga dapat melakukan pencarian dengan mudah dengan fasilitas textbox search yang berada di sebelah kanan atas dari halaman nasabah ini. Untuk melakukan penginputan ataupun update dari data nasabah digunakan form nasabah.

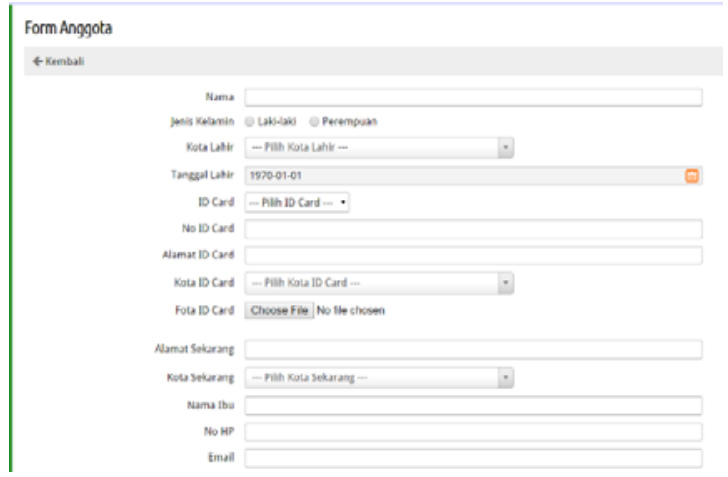

\section{Gambar 11. Form Nasabah}

\subsection{Halaman Pinjaman}

Halaman pinjaman merupakan halaman dimana admin mengelola data pinjaman dari seorang nasabah. Terdapat beberapa fungsi yang terdapat pada halaman ini. Fungsi dasar yang terdapat pada halaman ini adalah tambah, update, lihat dan hapus.

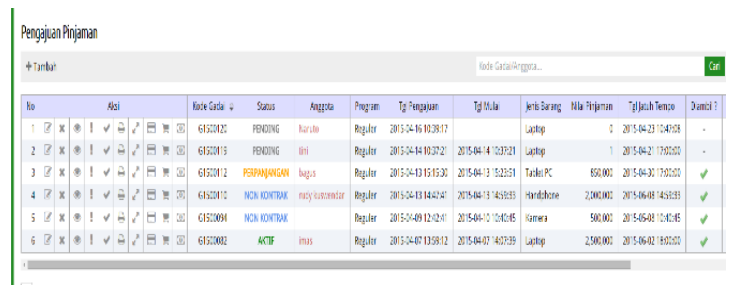

\section{Gambar 12. Halaman Pinjaman}

Untuk mengelola data pinjaman seperti tambah dan edit admin dapat menggunakan form pinjaman.

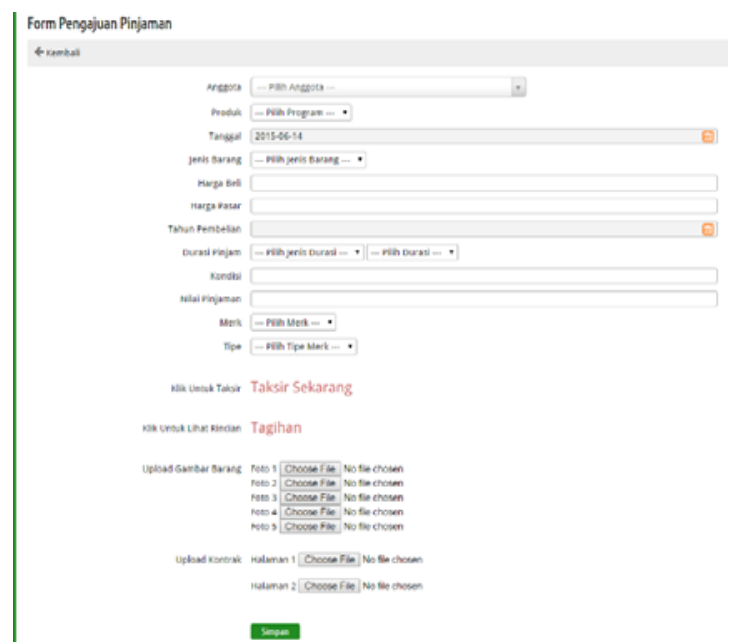

Gambar 13. Form Pinjaman

A. Verifikasi Pinjaman

Merupakan fitur yang berfungsi untuk melakukan verifikasi terhadap barang seorang nasabah yang ingin digadaikan. Jadi admin akan mencocokan keterangan dan foto barang yang 
diisikan oleh nasabah ke dalam form ketika melakukan pegadaian dengan bentuk fisik barang yang diterima oleh PT Pinjam Indonesia.

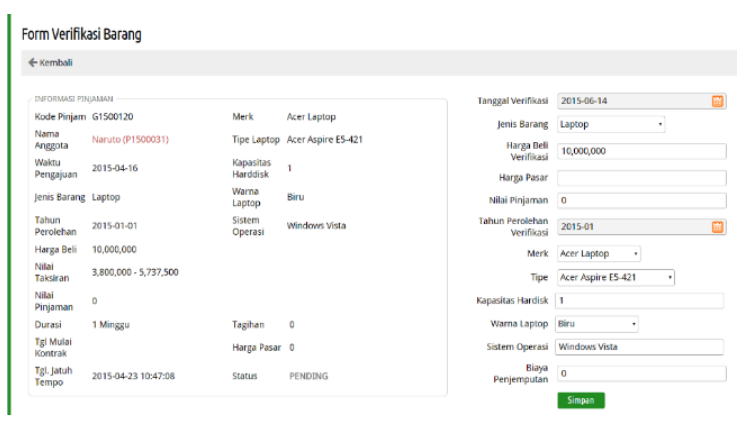

\section{Gambar 14. Form Verifikasi Pinjaman}

\section{Approval Pinjaman}

Setelah pinjaman diverifikasi oleh admin, maka admin akan menentukan pinjaman tersebut diterima atau tidak pada fitur Approval.

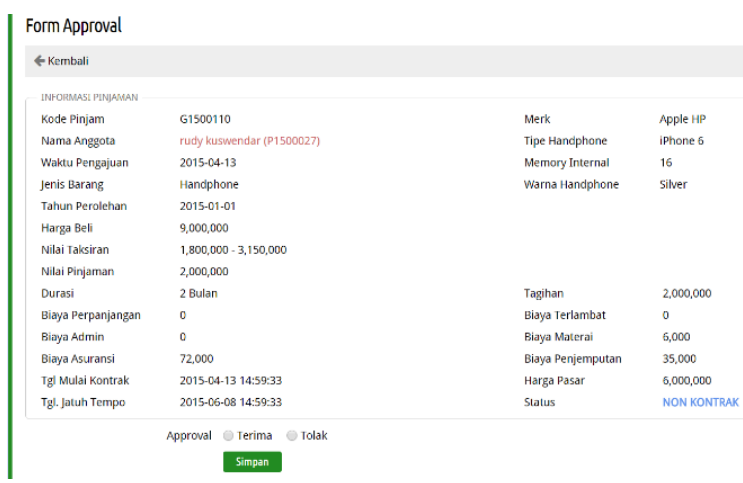

\section{Gambar 15. Form Approval Pinjaman}

\section{Perpanjang Pinjaman}

Merupakan fitur yang berfungsi untuk melakukan penambahan waktu durasi pinjaman. Dalam penambahan durasi pinjaman ini total maksimal durasi pinjaman adalah 12 minggu dan hanya dapat melakukan perpanjangan pinjaman sebanyak 1 kali.

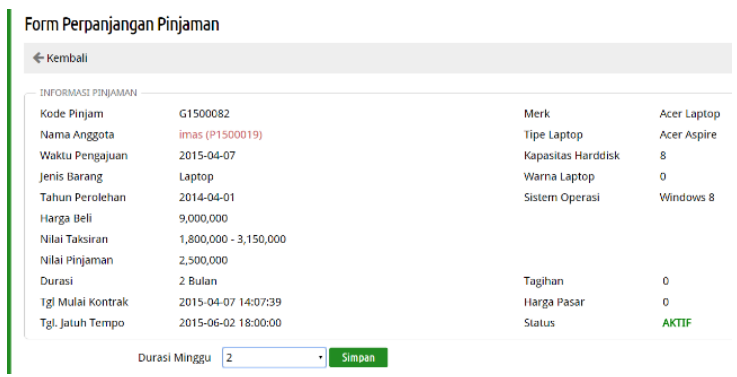

\section{Gambar 16. Form Perpanjangan Pinjaman}

\section{Pembayaran Pinjaman}

Merupakan fitur yang berfungsi untuk melakukan konfirmasi pembayaran yang diinputkan oleh customer di website. Proses pembayaran dapat dilakukan 2 kali.

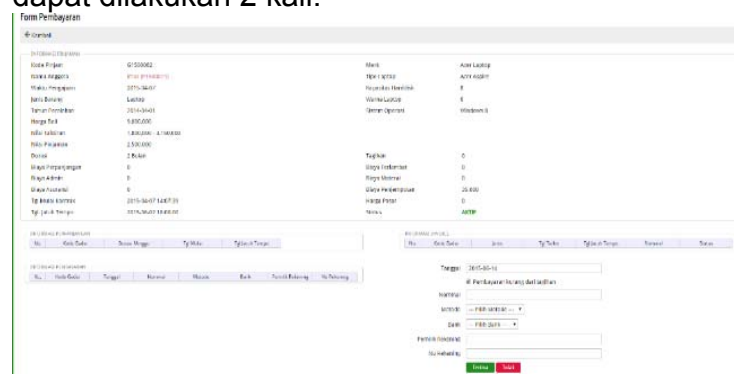

Gambar 17. Form Pembayaran Pinjaman

\subsection{Halaman Laporan}

Pada halaman laporan ini admin dapat melakukan rekapitulasi data yang terdapat di Sistem Pegadaian Online. Terdapat dua jenis laporan yaitu keuangan dan pinjaman.

A. Laporan Pinjaman

Laporan yang berisi data pinjaman sesuai dengan parameter yang diinputkan oleh admin. Parameter tersebut yaitu tanggal, anggota, kota domisili, jenis barang dan status pinjaman.

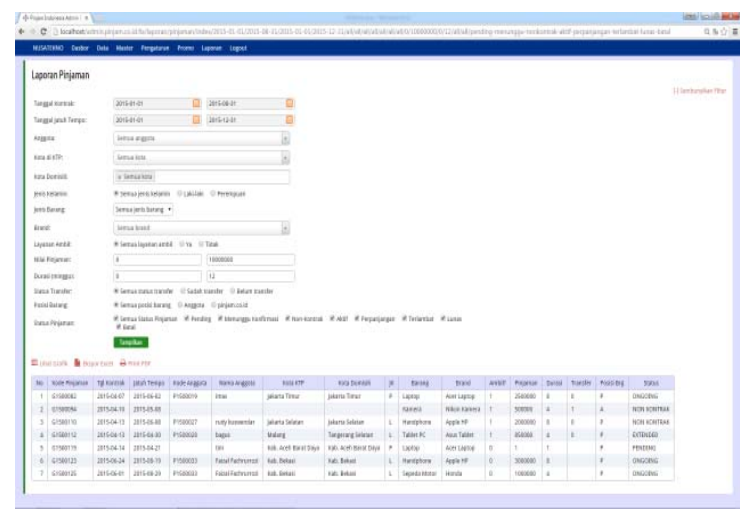

Gambar 18. Form Laporan Pinjaman

4. Laporan Keuangan

Laporan yang berisi data transaksi keuangan nasabah berdasarkan parameter yang diinputkan oleh admin. Parameter tersebut yaitu tanggal, kota domisili, jenis barang dan tahun. 


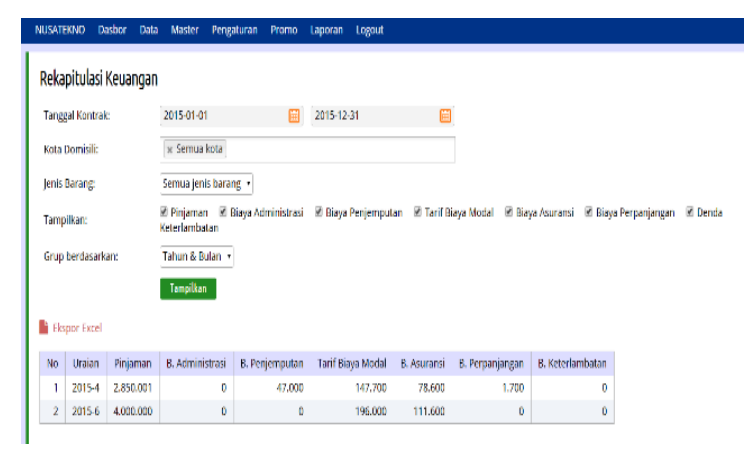

Gambar 19. Form Laporan Keuangan

1.8. Halaman Produk Gold

Pada halaman produk ini merupakan halaman dimana admin menentukan nasabah yang mendapatkan produk Gold. Pada halaman ini metode Simple Additive Weighting (SAW) diterapkan untuk menyeleksi nasabah penerima produk Gold. Adapun paremeter di halaman ini adalah periode dan tahun.

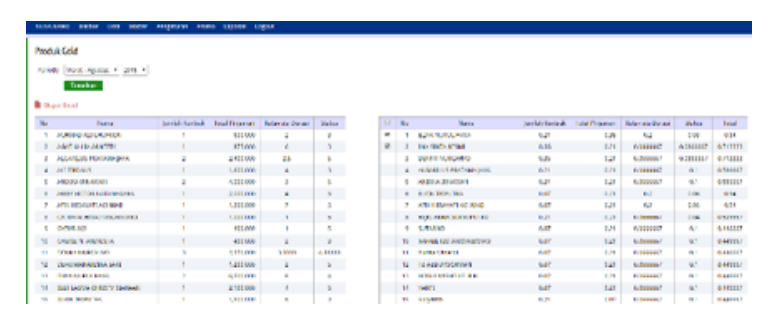

\section{Gambar 20. Halaman Produk Gold}

\section{KESIMPULAN}

\subsection{Kesimpulan}

Dari hasil penelitian yang dilakukan dari tahap awal hingga proses pengujian, dengan adanya aplikasi ini dapat disimpulkan bahwa :

1. Berdasarkan hasil uji coba yang dilakukan pada Bagian 4, metode Simple Additive Weighting dapat diterapkan pada studi kasus PT Pinjam Indonesia. Sistem tersebut dapat menentukan nasabah penerima produk Gold di PT Pinjam Indonesia periode bulan Maret sampai Agustus tahun 2015 sesuai dengan kriteria yang ditetapkan dengan nasabah yang terpilih adalah Eliya Nurul Haya dan Faizal Fachrurrozi.

2. Penerapan Simple Additive Weighting dalam Sistem Pegadaian Online dapat memberikan rekomendasi nasabah penerima produk Gold yang lebih objektif karena dapat dilakukan pembobotan terhadap kriteria yang telah ditentukan.

\subsection{Saran}

Dalam Sistem Informasi Laporan Manajemen Keuangan berbasis web memiliki kelebihan dan kekurangan sehingga apabila ingin melanjutkan penelitian lanjutan. Adapun beberapa hal yang dapat diperbaiki atau dilengkapi :

1. Format laporan keuangan dari masing-masing perusahaan sebaiknya memiliki format yang sama satu sama lain sehingga memudahkan dalam menganalisa laporan tersebut.

2. Pemilihan dari jasa hosting website lebih diperhatikan agar keamanan dan kecepatan akses untuk membuka website tersebut lebih baik.

3. Pemberian tanggapan baik pada bagian afiliasi perusahaan maupun yayasan dilakukan sesegera mungkin sehingga lebih cepat menganalisa kinerja perusahaan.

\section{DAFTAR PUSTAKA}

1. Hadi, M. (2013, July 15). Pengertian dan Sifat-sifat Gadai. Retrieved from http://pustakabakul.blogspot.com/2013/07/pen gertian-dan-sifat-sifat-gadai.html

2. Manokaran, E. Senthilvel, S. Subhashini, S. Dr Muruganandham, R. Dr Ravichandran, K. 2012. Mathematical Model for Performance Rating in Software industry-A study using Artificial Neural Network

3. Nugraha, Fajar. Surarso, Bayu. Noranita, Beta. 2012. Sistem Pendukung Keputusan Evaluasi Pemilihan Pemenang Pengadaan Aset dengan Metode Simple Additive Weighting (SAW)

4. Pratiwi, Dyah. Juliana, Putri, Lestari. Dewi, Agushinta. 2014. Decision Support System to Majoring High School Student Using Simple Additive Weighting Method

5. Ramakhrisnan, Raghu. Gehrke, Johannes. 2003. Sistem Manajemen Database (Edisi Ketiga)Yogyakarta: Andi

6. Simarmata, Janner. 2010. Rekayasa Perangkat Lunak : ANDI.

7. Sukaman, Ramdhani, Erick. 2012. Pendekataan Simple Additive Weighting (Saw) Untuk Menentukan Penerima Beasiswa Pada Stikom Binaniaga Bogor

8. Unger, Herwig. Kyamakya, Kyandoghere. Kacprzyk, Janusz. 2011. Autonomous Systems: Developments and Trends. Berlin. Springer 